\title{
Healthcare Students' Perceptions towards Using e-learning, and Self-reported Drivers and Barriers during COVID-19 Pandemic
}

\author{
Mukhtar Ansari ${ }^{1, *}$, Farhan Alshammari ${ }^{2}$, Hassan Alqahtani ${ }^{1}$, Raad Alshammari ${ }^{1}$, Mohammed Althubyani ${ }^{1}$, Turki Al Hagbani ${ }^{2}$, \\ Bushra Alshammari ${ }^{3}$ \\ 'Department of Clinical Pharmacy, College of Pharmacy, University of Hail, Hail, SAUDI ARABIA \\ 2Department of Pharmaceutics, College of Pharmacy, University of Hail, Hail, SAUDI ARABIA. \\ 3Department of Medical Surgical Nursing, College of Nursing, University of Hail, Hail, SAUDI ARABIA.
}

\begin{abstract}
Background: COVID-19 pandemic has reignited interest in online education as an appealing alternative. The study's goal was to evaluate students' perception of using e-learning, and to identify drivers and barriers the students experienced to the application of e-learning tools. Materials and Methods: This cross-sectional study was conducted between March 2020 and May 2020. The data was obtained using a self-administered questionnaire from the students adopting a census sampling method. The findings of Lean et al., as well as the study's objectives, were used to develop the questionnaire. The data was evaluated for descriptive and inferential analyses using SPSS version 21 (IBM Corporation, Armonk, NY, USA). Results: More than one half (52.7\%) of the total students ( $n=228)$ opined e-learning as a useful method for grasping basic concepts and coming up with new ideas. Pictures, graphs, videos, illustrations, and case studies were among the most beneficial aspects of e-learning (56.1\%). The ease of communicating electronically $(p=0.045)$ and smoother interaction between instructor and student $(p=0.050)$ were the major motivators across the colleges. Sluggish internet $(p=0.010)$, misunderstanding about
\end{abstract}

the importance of the study material $(p=0.007)$ and ambiguity about where to begin ( $p=0.048$ ) were the three significant issues encountered during e-learning across the gender. The most significant disadvantage of having more internet access as a result of online learning was that students spent a significant proportion of their daily time on non-academic activities. Conclusion: Electronic learning is a useful and productive educational tool particularly during the COVID-19 pandemic. Images, charts, videos, illustrations and case studies can all help to highlight its beauty.

Key words: COVID-19, E-learning, Healthcare, Perception, Saudi Arabia, Students.

Correspondence

Dr. Mukhtar Ansari,

Department of Clinical Pharmacy, College of Pharmacy, University of Hail, Hail, SAUDI ARABIA.

Email id: mukhtaransari@hotmail.com

DOI: 10.5530/jyp.2022.14.17

\section{INTRODUCTION}

Recent advances in information technology have a profound impact on various aspects of our daily lives, including education. ${ }^{1}$ E-learning is a relatively recent technique in higher education that offers an appealing alternative to traditional teaching-learning, particularly for academic institutions with limited resources. ${ }^{2,3}$ In order to stay competitive, many higher education institutions have adopted electronic learning as a teaching tool due to convenience, usefulness and acceptance. ${ }^{4}$ Following the declaration of the COVID-19 outbreak as a global pandemic by the World Health Organization (WHO), every area, including education, has been severely impacted. Due to the pandemic, the whole world was placed on lockdown, and colleges and schools stayed closed. COVID-19, on the other hand, has reignited a desire to educate online and online platforms could play an important role in organizing, preparing, delivering and monitoring the learning process during this pandemic., E-learning is gaining traction in higher education owing to its simplicity and numerous features, such as a range of teaching methods and course design. ${ }^{7}$ Online education enables students to learn at their own speed in order to attain the best possible results. ${ }^{8,9}$ E-learning tools, when used correctly, have various benefits for both students and instructors, including accessibility and ease of access to information. ${ }^{10-14}$

Saudi Arabia, a leading country in the Gulf region, is making strides in the area of electronic learning and is one of the leading countries in terms of rapid adoption of technology. In Saudi Arabia, Blackboard, an online course management program, is gaining popularity quickly. ${ }^{15}$ It has interactive teaching-learning features, as well as a variety of assessment methods and the ability to monitor students' activities. Saudi Arabia is eager to adopt new technology in the higher education sector in order to improve educational quality by immersive teaching and learning. It has also called for a "public strategy to implement information technology across the country" to support this.

Due to the COVID-19 pandemic, there was a global push to transition to online learning; thus a number of studies on electronic learning were done, mostly focusing on the need of online learning and learning process. ${ }^{16-22}$ Few studies, on the other hand, provided insight into university students' perceptions of adopting e-learning and the hurdles they faced during the pandemic's early stages, when the entire world was split on how to handle the problem. Hence, this study was devised with the objectives to evaluate students' perception of using e-learning, and to identify drivers and barriers the students experienced to the application of e-learning tools.

\section{MATERIALS AND METHODS}

\section{Study design}

This was a cross-sectional institution based prospective study. The study was carried out in accordance with the ethical principles set out by the institutional research committee. This research was endorsed by the Research Ethics Committee at the University of Hail, Saudi Arabia with research project No: H-2020-055. 


\section{Study duration and location}

The study was conducted between March 2020 and May 2020 at various health related colleges of the University of Hail, Saudi Arabia.

\section{Sample size and sampling procedure}

The population of this study was University students, and we choose to sample the entire population, hence the sample size in this study is the complete population. However, all of the students did not take part in the survey. A total of 228 students completed the survey and the participants were sampled from the study population using a census sampling method.

\section{Study tool}

A self-designed survey questionnaire was used in this analysis. The study's objectives guided the creation of the questionnaire. Faculty from the University of Hail's College of Pharmacy assessed the tool's face and content validity. Test-retest was used to determine the questionnaire's reliability. The questionnaire was piloted with a small group of randomly selected participants, and necessary changes were made based on their responses. The findings of Lean et al. ${ }^{23}$ as well as the study's objectives, were used to develop the questionnaire, and is consisted of four parts (A-demographic characteristics, B-opinion or view about e-learning, $\mathrm{C}$-reasons for preferring e-learning, and D-barriers to e-learning). Participation in the study was entirely voluntary.

\section{Data collection and analysis}

Level four, six, eight, and 10 students enrolled in different health related undergraduate programs (session 2019-2020) were approached and the self-administered questionnaire was distributed to them by the data collectors. The data was entered in version 21 of SPSS (IBM Corporation, Armonk, NY, USA) and analyzed using required statistical methods for descriptive and inferential analyses. The Chi-square test was used to determine differences in categorical results.

\section{RESULTS}

Males made up 55.3 percent of the 228 participants. More than twothirds of the respondents were from pharmacy and dental schools (Table 1). Students perceived e-learning as a helpful way to grasp basic concepts and come up with new ideas. Images, graphs, videos, illustrations, and case

Table 1: Participants' Demographic Profile ( $n=228)$.

\begin{tabular}{cccc}
\hline \multirow{3}{*}{ Gender } & Mariables & Number & Percentage \\
& Female & 126 & 55.3 \\
Age & 19 to 22 years & 135 & 44.7 \\
& 23 to 26 years & 93 & 59.2 \\
& Pharmacy & 75 & 40.8 \\
College & Medicine & 24 & 32.9 \\
& Dental & 82 & 10.5 \\
& Nursing & 39 & 36.0 \\
& Public Health & 8 & 17.1 \\
& Level two & 21 & 3.5 \\
& Level four & 40 & 9.2 \\
& Level six & 59 & 17.5 \\
& Level eight & 41 & 25.9 \\
& Level ten & 67 & 18.0 \\
\hline
\end{tabular}

studies were among the most beneficial aspects of e-learning. However, the students at the University of Hail believed that a combination of online and traditional learning would be optimal. Students from various colleges showed significant associations with their preferred method of lecture delivery $(p=0.007)$, the type of presentation that students gain the most from $(p=0.017)$, and the time consumed on the internet for learning activities on a daily basis $(p<0.001)$ (Table 2$)$.

The convenience of electronic communication and the ease of interaction between the instructors and the students were two of the most motivating aspects of e-learning in college. There was a significant association between the ease of interacting online and the students of various colleges $(p=0.045)$ (Table 3 ).

Slow internet, apprehension about the content's meaning, and a lack of direction were the most common issues encountered by both genders during e-learning. Gender and uncertainty about the importance of content $(p=0.007)$ and uncertainty about where to begin $(p=0.048)$ had significant associations (Table 4).

Students accessed the internet for a considerable portion of their daily time for non-academic purposes (Figure 1).

\section{DISCUSSION}

Despite the fact that online classes became popular during the COVID-19 pandemic, students preferred face-to-face lectures because

Table 2: Students' Viewpoint on Learning Approaches across Colleges.

\begin{tabular}{|c|c|c|c|}
\hline \multicolumn{2}{|r|}{ Variables } & \multirow{2}{*}{$\frac{n(\%)}{127(55.7)}$} & \multirow[t]{2}{*}{$P$ value } \\
\hline \multirow{2}{*}{$\begin{array}{c}\text { The most favored } \\
\text { mode of delivery of } \\
\text { lectures }\end{array}$} & Face to face lecture & & \\
\hline & $\begin{array}{l}\text { Online live and recorded } \\
\text { session }\end{array}$ & $90(39.5)$ & $0.007^{\star}$ \\
\hline \multirow{2}{*}{$\begin{array}{c}\text { Type of } \\
\text { presentation } \\
\text { students learn the } \\
\text { most from }\end{array}$} & $\begin{array}{l}\text { Online interactive and } \\
\text { recorded lecture in Blackboard }\end{array}$ & $116(50.9)$ & \multirow{2}{*}{$0.017^{*}$} \\
\hline & Face to face lecture & $112(49.1)$ & \\
\hline \multirow{4}{*}{$\begin{array}{l}\text { The most preferred } \\
\text { available means for } \\
\text { asking questions } \\
\text { with instructors }\end{array}$} & $\begin{array}{l}\text { Meeting the teacher of the } \\
\text { course during office hours }\end{array}$ & $91(39.9)$ & \multirow{4}{*}{$0.002^{*}$} \\
\hline & $\begin{array}{l}\text { Conveying the issue through } \\
\text { class representative }\end{array}$ & $57(25)$ & \\
\hline & E-mailing the course teacher & $41(18)$ & \\
\hline & $\begin{array}{c}\text { Asking questions via an } \\
\text { anonymous Blackboard } \\
\text { discussion board }\end{array}$ & $39(17.1)$ & \\
\hline \multirow[t]{3}{*}{$\begin{array}{l}\text { E-learning as } \\
\text { helpful tool in }\end{array}$} & $\begin{array}{l}\text { Getting the fundamental } \\
\text { concept }\end{array}$ & $103(45.2)$ & \multirow{3}{*}{0.062} \\
\hline & $\begin{array}{l}\text { Getting focal idea and exposure } \\
\text { to practical applications }\end{array}$ & $67(29.4)$ & \\
\hline & Innovation & $17(7.5)$ & \\
\hline \multirow{3}{*}{$\begin{array}{l}\text { The most useful } \\
\text { part of the } \\
\text { e-learning }\end{array}$} & Images, charts and videos & $128(56.1)$ & \multirow{3}{*}{0.064} \\
\hline & Examples and case studies & $51(22.4)$ & \\
\hline & Contents & $49(21.5)$ & \\
\hline \multirow{3}{*}{$\begin{array}{l}\text { Time spent on } \\
\text { internet daily for } \\
\text { academic activities }\end{array}$} & Up to an hour & $60(26.3)$ & \multirow{3}{*}{$<0.001^{*}$} \\
\hline & Two to four hours & $115(50.4)$ & \\
\hline & More than four hours & $53(23.3)$ & \\
\hline \multirow{3}{*}{$\begin{array}{c}\text { Preferences } \\
\text { of learning } \\
\text { environment in } \\
\text { future }\end{array}$} & $\begin{array}{l}\text { A blend of online and } \\
\text { traditional learning }\end{array}$ & $131(57.4)$ & \multirow{3}{*}{0.086} \\
\hline & E-learning & $56(24.6)$ & \\
\hline & Traditional learning & $41(18)$ & \\
\hline
\end{tabular}

* represents significant associations (Chi-square; $p$-value <0.05) 
Table 3: Factors Encouraging Students Towards E-learning Across Colleges.

\begin{tabular}{|c|c|c|}
\hline Variables & $n(\%)$ & $P$ value \\
\hline Flexible time for learning & $191(83.8)$ & 0.204 \\
\hline $\begin{array}{l}\text { Easy and effective control of time for completion } \\
\text { of assignments }\end{array}$ & $179(78.5)$ & 0.673 \\
\hline No access limit to electronic learning & $179(78.5)$ & 0.205 \\
\hline The opportunity to learn at one's own pace & $174(76.3)$ & 0.985 \\
\hline $\begin{array}{l}\text { Learn appropriate programming skills to do } \\
\text { online work }\end{array}$ & $166(72.8)$ & 0.998 \\
\hline Convenience in electronic communication & $166(72.8)$ & $0.045^{*}$ \\
\hline Easier to grasp & $163(71.5)$ & 0.116 \\
\hline Encouragement from close friends/someone & $143(62.7)$ & 0.064 \\
\hline $\begin{array}{c}\text { More inspiring to learn electronically outside of } \\
\text { class }\end{array}$ & $140(61.4)$ & 0.770 \\
\hline $\begin{array}{l}\text { Easier interaction between instructor and } \\
\text { students }\end{array}$ & $138(60.5)$ & $0.050^{*}$ \\
\hline Easier to appear in tests electronically & $135(59.2)$ & 0.597 \\
\hline
\end{tabular}

${ }^{*}$ represents significant associations (Chi-square; $p$-value $<0.05$ )

Table 4: Problems Encountered During E-learning Across Gender.

\begin{tabular}{ccc}
\hline Variables & $\boldsymbol{n}(\%)$ & $\boldsymbol{P}$ value \\
\hline Sluggish internet & $195(85.5)$ & $0.010^{*}$ \\
Unsure about the content's importance & $139(61)$ & $0.007^{*}$ \\
Prefer to learn in class & $132(57.9)$ & 0.580 \\
Lack of interest & $130(57)$ & 0.116 \\
Get confused & $127(55.7)$ & 0.119 \\
Excessive information & $119(52.2)$ & 0.071 \\
Uncertain about where to begin & $102(44.7)$ & $0.048^{*}$ \\
Difficult to follow & $101(44.3)$ & 0.827 \\
\hline
\end{tabular}

${ }^{*}$ represents significant association (Chi-square; $p$-value $<0.05$ )

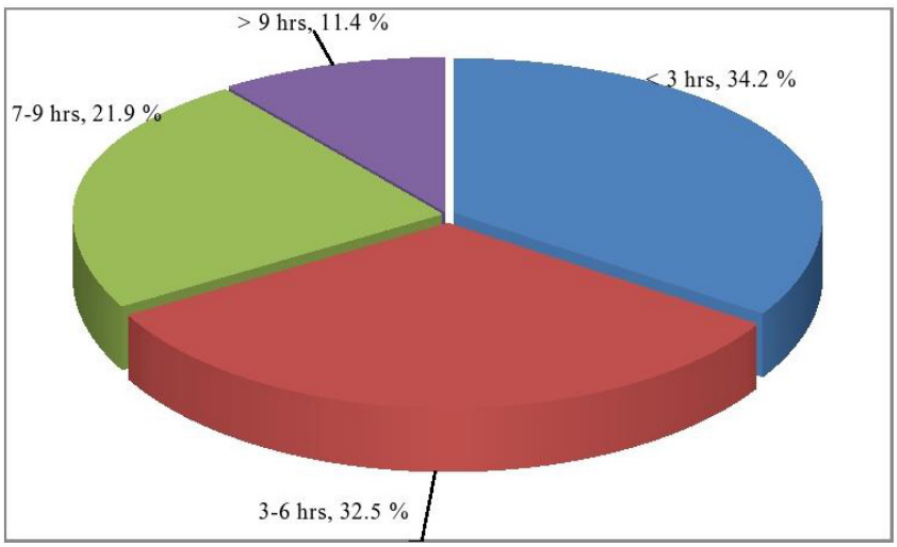

Figure 1: Normal time spent on the internet for Non-academic activities.

they face numerous issues when taking online classes, including a lack of stimulus and understanding of the study materials, a decrease in communication between students and instructors, and a sense of isolation caused by online classes. ${ }^{24}$ On the other hand, students learned the most fundamental concepts using an innovative online interactive and recorded lecture in Blackboard. This is because students have the freedom to study at their own speed in order to improve educational outcomes. ${ }^{8}$ Furthermore, online teaching allows for greater flexibility and accessibility to materials. ${ }^{10,11}$ Students preferred to meet with the course instructor during office hours for guidance rather than conversing online if they had any questions. This is due to the fact that students get vital information, insight on how to conduct their course work, and overall trust. ${ }^{24,25}$ The most effective features of e-learning, according to students, are images, charts, videos, examples, and case studies. ${ }^{26-28}$

More than three-fourth of students consumed four hours a day on internet for academic purposes. On the contrary, almost two-thirds of students spent six hours a day online for non-academic purposes, while the remaining one-third spent seven hours or more a day online for nonacademic purposes. The use of the internet for educational purposes is advantageous in terms of increasing knowledge and understanding, but its main drawback is the transition to social media and non-academic activities, which leads to diversion from academic activities and ultimately poor academic results. ${ }^{29-31}$

The most driving aspects for students to adopt e-learning were time flexibility for studying and completing assignments, infinite access to learn and understand at one's own pace, the possibility to obtain necessary programming abilities, and the convenience of communicating electronically. Other driving factors included close mates, easier contact with the instructor, and the ability to appear in tests. ${ }^{32-34}$

Despite the fact that there are numerous motivational aspects to boost electronic learning, there are also numerous obstacles to overcome. Some of them include slow internet, doubt about the content's relevancy, and lack of long-term interest, confusion, and superfluous detail, not knowing where to begin, and being difficult to follow. ${ }^{24,25,35}$

Since both traditional and online learning have benefits and drawbacks, students' choice for the future will be a hybrid of the two. This viewpoint aligns with the outcome of a study conducted by Amir et al. ${ }^{36}$ When paired online learning with classroom-based learning programs, its effect can be amplified. ${ }^{12}$ This hybrid approach refers to a formal combination of online and face-to-face approaches to foster and establish significant communication among course instructors, students, and resources. ${ }^{13}$ Integrated online learning offers a lot of flexibility and responsiveness in the process of educating and instructing. ${ }^{14}$

The study's limitation was its small sample size, which was due to the fact that only students from healthcare colleges were recruited. More multicenter studies involving students and instructors are recommended for more detailed findings.

\section{CONCLUSION}

Without a doubt, e-learning is a useful instrument for learning fundamental principles and creating new concepts. To emphasize its beauty, images, charts, videos, illustrations, and case studies can all be used. Electronic learning has numerous advantages, but it also has a lot of disadvantages. To summarize, a blend of online and conventional learning is required for optimal results.

\section{ACKNOWLEDGEMENT}

The Research Ethics Committee at the University of Hail in Saudi Arabia approved the study, which the authors are grateful for. We would also like to express our gratitude to the College of Pharmacy at the University of Hail, for allowing us to conduct this study.

\section{CONFLICT OF INTEREST}

The authors declare no conflict of interest. 


\section{REFERENCES}

1. Chivu R, Turlacu L, Stoica I, Radu A. Identifying the effectiveness of e-learning platforms among students using eye-tracking technology. Proceedings of the $4^{\text {th }}$ international conference on Higher Education Advances; Jun 20-22 2018; Valencia, Spain: Editorial Universitat Politècnica de València; 2018.

2. Wagner N, Hassanein K, Head M. Who is responsible for e-learning success in higher education? A stakeholders' analysis. Educ Technol Soc. 2008;11(3):26-36.

3. Mpungose CB. Emergent transition from face-to-face to online learning in a South African University in the context of the coronavirus pandemic. Humanit Soc Sci Commun. 2020;7(1):113. doi: 10.1057/s41599-020-00603-x.

4. Zalat MM, Hamed MS, Bolbol SA. The experiences, challenges, and acceptance of e- learning as a tool for teaching during the COVID-19 pandemic among university medical staff. PLOS ONE. 2021;16(3):e0248758. doi: 10.1371/journal. pone.0248758, PMID 33770079

5. Saudigazette.com.sa [homepage on the Internet]. Saudi Arabia: e-learning may be strategic choice post-corona crisis: Saudi minister. Saudi Gazette [cited dec 132020]. Available from: https://saudigazette.com.sa/article/592102/SAUDI-ARABIA/ E-learning-may-be-strategic-choicepost-corona-crisis-Saudi-minister; 2020.

6. Ansari M. COVID-19 pandemic and an urgent need of online learning approaches in Nepal and other developing nations. Birat J Health Sci. 2020;5(1):877-8. doi: 10.3126/bjhs.v5i1.29652.

7. Gonzalvo JD, Chomicki JR, Chu MA, Frail CK. Incorporation of online clinical topic modules in an introduction to advanced pharmacy practice experience course. Curr Pharm Teach Learn. 2013;5(5):438-43. doi: 10.1016/j.cptl.2013.06.001.

8. Elliott RA, McDowell J, Marriott JL, Calandra A, Duncan G. A pharmacy preregistration course using online teaching and learning methods. Am J Pharm Educ. 2009;73(5):77. doi: 10.5688/aj730577, PMID 19777092

9. Al Zahrani EM, Al Naam YA, AlRabeeah SM, Aldossary DN, Al-Jamea LH, Woodman A, et al. E- Learning experience of the medical profession's college students during COVID-19 pandemic in Saudi Arabia. BMC Med Educ. 2021;21(1):443. doi: 10.1186/s12909-021-02860-z, PMID 34416889.

10. Lam P, McNaught $C$, Lee J, Chan M. Disciplinary difference in students' use of technology, experience in using elearning strategies and perceptions towards elearning. Comput Educ. 2014;73:111-20. doi: 10.1016/j.compedu.2013.12.015.

11. Hubackova S. Pedagogical foundation of elearning. Procedia Soc Behav Sci. 2014;131:24-8. doi: 10.1016/j.sbspro.2014.04.073.

12. Benta D, Bologa G, Dzitac S, Dzitac I. University Level learning and teaching via e-learning platforms. Procedia Comput Sci. 2015;55:1366-73. doi: 10.1016/j. procs.2015.07.123.

13. Garrison DR, Kanuka H. Blended learning: Uncovering its transformative potential in higher education. The Internet and Higher Education. 2004;7(2):95-105 doi: 10.1016/j.iheduc.2004.02.001.

14. Lewin LO, Singh M, Bateman BL, Glover PB. Improving education in primary care: Development of an online curriculum using the blended learning model. BMC Med Educ. 2009;9(1):33. doi: 10.1186/1472-6920-9-33, PMID 19515243.

15. Alkhalaf $S$, Drew $S$, Alhussain T. Assessing the impact of e-learning systems on learners: A survey study in the KSA. Procedia Soc Behav Sci. 2012;47:98-104. doi: 10.1016/j.sbspro.2012.06.620

16. Khalil R, Mansour AE, Fadda WA, Almisnid K, Aldamegh M, Al-Nafeesah A, et al. The sudden transition to synchronized online learning during the COVID-19 pandemic in Saudi Arabia: A qualitative study exploring medical students' perspectives. BMC Med Educ. 2020;20(1):285. doi: 10.1186/s12909-02002208-z, PMID 32859188.

17. Pokhrel S, Chhetri R. A literature review on impact of COVID-19 pandemic on teaching and learning. Higher Educ Future. 2021;8(1):133-41. doi:
$10.1177 / 2347631120983481$

18. Engzell $P$, Frey A, Verhagen MD. Learning loss due to school closures during the COVID-19 pandemic. Proc Natl Acad Sci USA. 2021;118(17):e2022376118. doi: 10.1073/pnas.2022376118, PMID 33827987

19. Dhawan S. Online learning: A panacea in the time of COVID-19 crisis. J Educ Technol Syst. 2020;49(1):5-22. doi: 10.1177/0047239520934018.

20. Mishra L, Gupta T, Shree A. Online teaching-learning in higher education during lockdown period of COVID-19 pandemic. Int J Educ Res Open. 2020;1. doi: 10.1016/j.ijedro.2020.100012, PMID 100012

21. Gurung S. Challenges faced by teachers in online teaching during COVID-19 pandemic. Online J Distance Educ Elearn. 2021;9(1):8-18.

22. Okoye K, Rodriguez-Tort JA, Escamilla J, Hosseini S. Technology-mediated teaching and learning process: A conceptual study of educators' response amidst the Covid-19 pandemic. Educ Inf Technol (Dordr). 2021;26(6):7225-57.

23. Lean QY, Ming LC, Wong YY, Neoh CF, Farooqui M, Muhsain SNF. Validation of online learning in pharmacy education: effectiveness and student insight. Pharm Educ. 2018;18(1):135-42

24. Coman C, Tîru LG, Mesesan-Schmitz L, Stanciu C, Bularca MC. Online teaching and learning in higher education during the coronavirus pandemic: Students perspective. Sustainability. 2020;12(24):10367. doi: 10.3390/su122410367.

25. Wut TM, Xu J. Person-to-person interactions in online classroom settings under the impact of COVID-19: A social presence theory perspective. Asia Pacific Educ Rev. 2021;22(3):371-83. doi: 10.1007/s12564-021-09673-1.

26. Bobek E, Tversky B. Creating visual explanations improves learning. Cogn Res Princ Implic. 2016;1(1):27. doi: 10.1186/s41235-016-0031-6, PMID 28180178.

27. Escartín J, Saldaña O, Martín-Peña J, Varela-Rey A, Jiménez Y, Vidal T, et al. The impact of writing case studies: Benefits for students' success and well-being. Procedia Soc Behav Sci. 2015;196:47-51. doi: 10.1016/j.sbspro.2015.07.009.

28. Bonney KM. Case study teaching method improves student performance and perceptions of learning gains. J Microbiol Biol Educ. 2015;16(1):21-8. doi: 10.1128/jmbe.v16i1.846, PMID 25949753.

29. Feng S, Wong YK, Wong LY, Hossain L. The internet and Facebook usage on academic distraction of college students. Comput Educ. 2019;134(1):41-9. doi: 10.1016/j.compedu.2019.02.005.

30. Giunchiglia F, Zeni M, Gobbi E, Bignotti E, Bison I. Mobile social media usage and academic performance. Comput Hum Behav. 2018;82:177-85. doi: 10.1016/j.chb.2017.12.041.

31. Felisoni DD, Godoi AS. Cell phone usage and academic performance: An experiment. ComputEduc. 2018;117:175-87. doi: 10.1016/j.compedu.2017.10.006.

32. Balle $S$, Petersen A, Nortvig A. A literature review of the factors influencing e-learning and blended learning in relation to learning outcome, student satisfaction and engagement. Electron J e-Learning. 2018;16(1):46-55.

33. Luaran JE, Samsuri NN, Nadzri FA, Rom KBM. A study on the student's perspective on the effectiveness of using e-learning. Procedia Soc Behav Sci. 2014;123:139-44. doi: 10.1016/j.sbspro.2014.01.1407.

34. Mukhtar K, Javed K, Arooj M, Sethi A. Advantages, limitations and recommendations for online learning during COVID-19 pandemic era. Pak J Med Sci. 2020;36(COVID19-S4):S27-31. doi: 10.12669/pjms.36.COVID19-S4.2785, PMID 32582310.

35. Muilenburg LY, Berge ZL. Student barriers to online learning: A factor analytic study. Distance Educ. 2005;26(1):29-48. doi: 10.1080/01587910500081269.

36. Amir LR, Tanti I, Maharani DA, Wimardhani YS, Julia V, Sulijaya B, et al. Student perspective of classroom and distance learning during COVID-19 pandemic in the undergraduate dental study program Universitas Indonesia. BMC Med Educ. 2020:20(1):392. doi: 10.1186/s12909-020-02312-0, PMID 33121488.

Article History: Received: 01-10-2021; Revised: 28-11-2021; Accepted: 03-12-2021

Cite this article: Ansari M, Alshammari F, Alqahtani H, Alshammari R, Althubyani M, HagbaniTA, Alshammari B. Healthcare Students' Perceptions towards using e-learning, and Self-reported Drivers and Barriers during COVID-19 Pandemic. J Young Pharm. 2022;14(1):89-92. 